\title{
PELAKSANAAN KEGIATAN ADVOKASI 'PATWAL' PBI BPJS KESEHATAN DAN ADVOKASI DTD (DOOR TO DOOR) KE MASYARAKAT TERKAIT KEPESERTAAN BPJS KESEHATAN DI DESA CIKUNIR KECAMATAN SINGAPARNA KABUPATEN TASIKMALAYA
}

\author{
Dadan Yogaswara, S.KM,M.KM \\ Milaty Hanifah \\ Email : dan_yogas@yahoo.com
}

\section{STIKes Respati}

\section{A. DASAR PEMIKIRAN}

Pelaksanaan JKN (Jaminan Kesehatan Nasional) dilandasi oleh UU No. 40 Tahun 2004 tentang Sistem Jaminan Sosial Nasional (SJSN) dan UU No. 24 Tahun 2011 tentang Badan Penyelenggara Jaminan Sosial (BPJS) yang diamanatkan untuk menyelenggarakan jaminan kesehatan bagi seluruh masyarakat Indonesia. Partisipasi peserta dilaksanakan secara bertahap dan diharapkan masyarakat wajib tercakup sebagai peserta tanpa adanya pengecualian (Kementrian Kesehatan, 2014).

Program jaminan sosial ini diselenggarakan oleh BPJS yang terbagi menjadi BPJS Kesehatan dan BPJS Ketenagakerjaan. Program JKN merupakan mekanisme asuransi kesehatan sosial yang bersifat nasional, wajib, nirlaba, gotong royong, dan ekuitas, untuk memenuhi kebutuhan dasar bagi kesehatan masyarakat yang telah membayar iuran atau iurannya dibayarkan oleh pemerintah (Kementrian Kesehatan, 2014). BPJS kesehatan merupakan salah satu program penjaminan pemeliharaan kesehatan yang diwajibkan oleh pemerintah. Sesuai pasal 14 UU BPJS setiap warga negara Indonesia dan warga asing yang sudah berdiam di Indonesia selama minimal enam bulan wajib menjadi anggota BPJS. Setiap orang atau keluarga yang tidak bekerja pada perusahaan wajib mendaftarkan diri dan anggota keluarganya pada BPJS. Setiap peserta BPJS akan ditarik iuran yang besarnya ditentukan kemudian. Sedangkan bagi warga miskin, iuran BPJS ditanggung pemerintah melalui program Bantuan Iuran.

Partisipasi masyarakat juga dipengaruhi oleh pengetahuan dan pemahaman tentang asuransi kesehatan. Pengukuran tingkat kesadaran, pengetahuan dan pemahaman dilakukan dengan melihat perbedaan gender, usia, dan tingkat pendidikan. Status sosial, pendidikan, pendapatan, dan pengeluaran dapat digunakan untuk menguji hubungan antara karakteristik individu dengan kesadaran dan pengetahuan mengenai asuransi kesehatan (Siswoyo, dkk., 2015: 119).

Berdasarkan kegiatan PBL III menunjukkan bahwa masyarakat Desa Cikunir responden yang tidak memiliki JKN mempunyai proposi tertinggi sebanyak 44 responden $(51,2 \%)$ dan yang memiliki JKN sebanyak 42 responden $(48,8 \%)$.

Berdasarkah hal diatas dibutuhkan upaya untuk meningkatan upaya meningkatan partisipasi mayarakat melalui kebijakan yang dikeluarkan oleh Pemerintahaan desa.

\section{B. TUJUAN}

1. Menetapkan kebijakan terhadap penjaminan masyarakat yang Penerima Bantuan Iuran (PBI) dari pemilihan sasaran hingga 
mendapatkan bantuan dengan pengawalan.

2. Menetapkan kebijakan terhadap peningkatan cakupan kepesertaan BPJS Kesehatan dengan melakukan Door to door (DTD) terhadap masyarakat

\section{SASARAN}

Sasaran dari kegiatan ini adalah Kepala Desa Cikunir

D. WAKTU DAN TEMPAT

Kegiatan ini dilaksanakan pada bulan Maret 2019

\section{E. HASIL KEGIATAN}

1. Kepala Desa tidak bisa memfasilitasi kegiatan tersebut dikarenakan tidak bisanya atau tidak adanya system yang menyataka bahwa pihak desa dapat mendampingi pihak yang mengurus bantuan (pihak kecamatan).Adapun pihak desa mengajukan bantuan ke pihak kecamatan dengan cara melobi.

2. Kepala Desa menyatakan mendukung kegiatan tersebut yang berupa pelatihan kader dan tokoh-tokoh masyarakat. Hal ini dibuktikan dengan surat pernyataan yang ditandatangani oleh bapak Kepala Desa Cikunir.

Berdasarkan hasil analisis pada PBL II, masyarakat yang terdata tidak memiliki JKN di Dusun Anggaraja sebanyak 44 responden $(51,2 \%)$ dari jumlah responden $86 \mathrm{KK}$. Dalam menyelesaikan masalah tersebut, maka pelaksana melakukan kegiatan beberapa kegiatan sebagai berikut:

\section{a. Advokasi 'Patwal' PBI BPJS Kesehatan}

Kegiatan advokasi yang dilakukan pada Sabtu, 16 maret 2019 di rumah kepala desa. Kegiatan tersebut berjalan lancar namun ketika berdiskusi kembali dengan kepala desa, ada suatu hal yang menambah faktor penyebab yang membuat kenyataan sebenarnya terungkap.

Hasil kegiatan tersebut yaitu, Kepala Desa tidak bisa memfasilitasi kegiatan tersebut dikarenakan tidak bisanya atau tidak adanya system yang menyatakan bahwa pihak desa dapat mendampingi pihak yang mengurus bantuan (pihak kecamatan). Adapun pihak desa mengajukan bantuan ke pihak kecamatan dengan cara melobi. Hal tersebut menjadikan tidak adanya kesepakatan.

\section{b. Advokasi DTD (door to door) ke masyarakat terkait kepesertaan BPJS Kesehatan}

Kegiatan advokasi yang dilakukan pada Sabtu, 16 maret 2019 di rumah kepala desa bersamaan dengan topi advokasi 'Patwal' PBI. BPJS. Kegiatan tersebut berjalan lancar dengan keluarnya kesepakatan. Adapun hasil kegiatan tersebut yaitu, Kepala Desa menyatakan mendukung kegiatan tersebut yang berupa pelatihan kader dan tokoh-tokoh masyarakat. Hal ini dibuktikan dengan surat pernyataan yang ditandatangani oleh bapak 
F. DOKUMENTASI
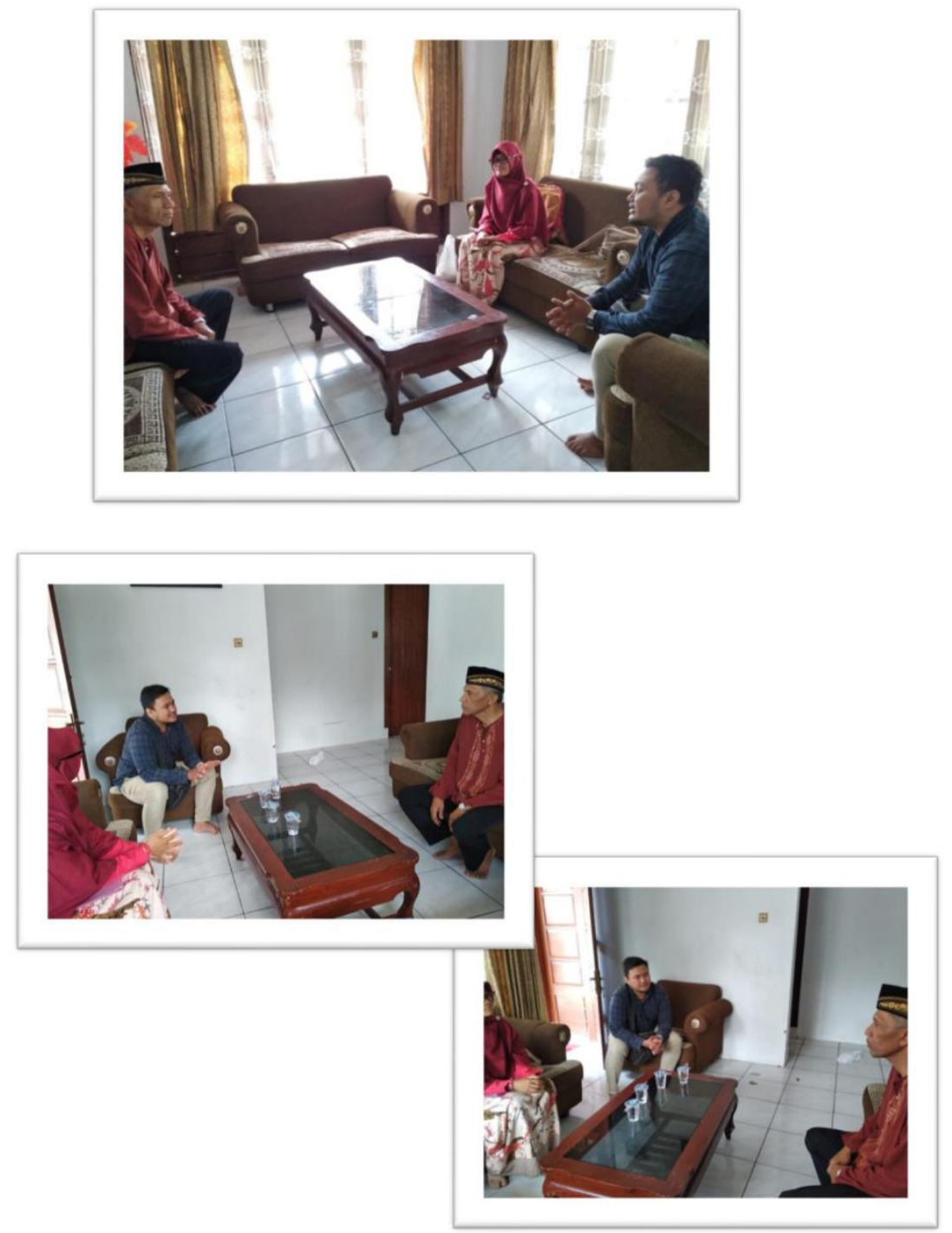